\title{
Conceptual Evaluation of the Potential Role of Fractures in Unsaturated Processes at Yucca Mountain
}

\author{
J. J. Hinds* \\ G. S. Bodvarsson \\ G. H. Nieder-Westermann \\ Earth Sciences Division, Lawrence Berkeley National Laboratory, Berkeley, CA 94702, USA \\ * Corresponding Author. Fax 510-486-6115; email: jhinds@lbl.gov
}

\begin{abstract}
A wide array of field observations, in situ testing, and rock and water sampling (and subsequent analyses) within the unsaturated zone of Yucca Mountain demonstrate the importance of fractures to flow and transport in the welded tuffs. The abundance of fractures and the spatial variability in their hydraulic properties, along with the heterogeneity within lithologic formations, make evaluation of unsaturated processes occurring within the potential repository horizon complex. Fracture mapping and field testing show that fractures are well connected, yet considerable variation is seen within and between units comprising the potential repository horizon with regard to fracture trace length, spacing, permeability, and capillarity. These variations have important implications for the distribution and movement of water and solutes through the unsaturated zone. Numerical models designed to assess such phenomena as unsaturated flow, transport, and coupled thermal-hydrological processes each require their own conceptual model for fracture networks, in order to identify the subset of all fractures that is relevant to the particular study. We evaluate several process-dependent conceptual models for fractures and identify the relevant fracture subsets related to these processes.
\end{abstract}

Key Words: Yucca Mountain, fracture characteristics, conceptual model, repository 


\section{Introduction}

Characterization of fractures is fundamental to numerical modeling studies aimed at assessing subsurface flow and transport processes at Yucca Mountain, Nevada (Bodvarsson et al., 2000, 2001; Liu et al., 1998). Fractures are important structural discontinuities within the variably welded tuffs at Yucca Mountain, providing highly permeable pathways for air, liquid, and heat to flow through unsaturated rocks. Although it is estimated that billions of fractures exist in the unsaturated zone (UZ) (Doughty, 1999), the number of fractures relevant to performance assessment depends upon the process being evaluated (e.g., flow, transport, coupled processes). Thus, there is a need to establish a "process-based" approach for determining those fractures that are relevant to modeling studies.

Several tens of thousands of fractures have been mapped and described as part of Yucca Mountain site characterization activities. Despite this wealth of information, the mapped fracture data set is biased to the larger-trace-length fractures (greater than or equal to $1 \mathrm{~m}$ ). Underrepresented are the smaller-trace-length fractures, which are believed to account for a large percentage of all fractures, but which are impractical to map extensively. In addition to mapping studies that describe fracture geometry, in situ field tests have been conducted to evaluate and estimate fracture hydraulic characteristics (Wang et al., 1999, 2001). The results of these tests allow for interpretation of fracture attributes such as connectivity, air permeability, and porosity, and the extent to which flow within fractures interacts with the rock matrix.

Motivated by a need to address certain modeling concerns about fracture data usage raised during technical exchanges between the Department of Energy and the Nuclear Regulatory Commission, this paper discusses some of the conceptual models for fractures in the potential repository host horizon $(\mathrm{RHH})$ and their significance to repository performance. Specifically, 
the objectives of this paper are to evaluate the importance of fractures at different scales on various processes in the $\mathrm{UZ}$ and to evaluate the importance of including all or a subset of mapped fractures in the analysis of these processes.

We conclude that the subset of fracture data currently used for ambient mountain-scale flow modeling is appropriate, but that this subset lacks additional information needed to characterize transport and thermal-hydrological conditions. For these latter two processes, we suggest including data describing smaller-scale fractures than currently used in numerical analyses. Small fractures (those less than $1 \mathrm{~m}$ in length) may be of particular importance within the unit currently selected to host the majority of waste emplacement drifts by contributing to the rock's storage capacity and by enhancing matrix diffusion. In the near-drift environment, where vaporization and condensation would occur in the presence of sufficient heat, all fractures become important for flow and, thus, should be represented.

\section{Hydrogeologic Setting}

Situated in the southern part of the Great Basin (Figure 1) amid characteristic basin and range topography, Yucca Mountain is the erosional remnant of uplifted and tilted Miocene-aged volcanic strata. Arid conditions prevail in the region containing Yucca Mountain, with generally less than $25 \mathrm{~cm}$ of precipitation received per year at the site under present-day conditions (Hevesi, 2000). Most of the precipitation is returned to the atmosphere through evapotranspiration, allowing only a small amount of water to percolate through the 500-750 m thick UZ to the water table (Montazer and Wilson, 1984; Flint et al., 1994; Hevesi, 2000). Estimated net-infiltration rates over the potential repository area locally reach over $100 \mathrm{~mm} / \mathrm{yr}$ (usually associated with upper channels of washes), but typically range from about 0 to 30 
$\mathrm{mm} / \mathrm{yr}$, with a mean value of approximately $5 \mathrm{~mm} / \mathrm{yr}$ (standard deviation, $8 \mathrm{~mm} / \mathrm{yr}$; Hevesi, 2000).

\subsection{Lithology and Structure}

The volcanic sequence that embodies the UZ of Yucca Mountain consists primarily of pyroclastic flows with volumetrically small amounts of bedded tuff deposits and localized lava flows. Depositional, post-depositional, and mechanical processes determine the rock textures and structures, which relate to the physical properties of the rock. Rock layers are distinguished in part by degree of welding, crystallization, occurrence of cavities, fracture characteristics, and mineral alteration (Buesch et al., 1996). Welding is a post-depositional process whereby volcanic ash is compressed under elevated temperatures and pressures, thus reducing porosity and increasing bulk density of the rock. Welding zones are categorized as nonwelded to partially, moderately, or densely welded. Cavities occur (typically concentrated in certain stratigraphic intervals called "lithophysal zones") where volcanic gas concentrated in the densely welded tuffs as the rock cooled (Ross and Smith, 1961). In the densely welded tuffs at Yucca Mountain, cavities typically range in diameter from 1 to $50 \mathrm{~cm}$, but may locally reach $1 \mathrm{~m}$ or more in diameter.

The general lithostratigraphy at Yucca Mountain is illustrated in Figure 2, using the nomenclature and unit divisions defined by Sawyer et al. (1994) and Buesch et al. (1996). The Tiva Canyon and Topopah Spring Tuffs comprise the largest volume of rock in the UZ of Yucca Mountain. Except at their upper and lower margins, these simple cooling units are moderately to densely welded and highly fractured. Separating these two units are the variably thick Yucca Mountain and Pah Canyon Tuffs and their associated bedded tuffs, which are predominantly nonwelded and relatively unfractured in the potential repository area. Below the Topopah Spring 
Tuff lies the nonwelded Calico Hills Formation, whose vitric (i.e., glassy) matrix has been largely altered to low-permeability zeolites.

Although with varying density, fractures are present within all rock layers having formed in response to cooling, gravitational unloading, regional stress, and faulting. Numerous reports (Barton et al., 1993; Barr et al., 1996; Albin et al., 1997; Mongano et al., 1999) describe the different types of structural discontinuities (e.g., fractures, cooling joints, and faults) observed at Yucca Mountain. Barton et al. (1993) explain that the historic evolution of fracture patterns at Yucca Mountain, from initial cooling joint development to subsequent fracturing in response to tectonic stresses, has produced highly-connected fracture networks within the welded tuffs.

Major faults have very different hydrologic properties than cooling joints; they are usually larger and may form highly fractured zones with widths up to hundreds of meters. Because the current infiltration model does not associate faults with large catchment areas involving large volumes of infiltrating water, it is reasonable to assume that recharge through alluvial channels and the associated faults and other potential fast pathways above the potential repository horizon is minimal compared to the overall recharge flux (Liu, 2000). For these reasons, faults are not included in this conceptual discussion of fractures.

Within the potential repository host rock, matrix characteristics are fairly homogeneous (Flint, 1998); each unit of the RHH (i.e., lower portion of Tptpul, Tptpmn, Tptpll, and Tptpln) consists of compositionally similar, moderately to densely welded ash-flow tuff. However, these units exhibit different fracture characteristics (Buesch et al., 1996), which impose complex hydrogeologic heterogeneity within the potential-repository siting volume. The current draft repository design has over half of the potential waste emplacement drifts located within the lower lithophysal zone (Tptpll) of the Topopah Spring Tuff, with the remaining drifts divided 
roughly equally between the middle nonlithophysal zone (Tptpmn) and the lower nonlithophysal zone (Tptpln).

\subsection{Hydrologic Conditions}

Within the moderately to densely welded repository host rocks, flow in fractures (fracture flow) is orders of magnitude faster than flow within the rock matrix (matrix flow), leading to much shorter groundwater travel times in fractures compared to the matrix (Bodvarsson et al., 1999, 2000). Based on in situ field measurements and hydraulic properties calculated for core samples, the high density of interconnected fractures and the low matrix saturated-hydraulicconductivity values within the Topopah Spring Tuff relative to the estimated average infiltration rate are believed to give rise to significant water flow in fractures under ambient conditions (Pruess et al., 1999; Liu, 2000). Further evidence for fracture flow comes from observations of mineral coatings, such as calcite and opal, along some fracture walls of the moderately to densely welded tuffs, indicating historic water flow paths (Paces et al., 1998; Marshall et al., 1998). Geochemical analyses of perched-water samples show carbon-14 ages ranging from 3,500 to 11,000 years (Yang et al., 1996), which requires a significant fracture flow component given the low permeability of the rock matrix.

As expected in an unsaturated flow volume, not all connected fractures transmit water. Liu et al. (1998) estimate that, under ambient conditions, only about $18-27 \%$ of widely dispersed and connected fractures transmit water within the potential repository rocks. They further suggest that within an "active" fracture (i.e., one that transmits water), the matrix surface area in contact with percolating water is limited as a result of gravitationally driven flow fingering, a phenomenon demonstrated experimentally by Nicholl et al. (1994). For these reasons, it is believed that much of the fracture system under ambient conditions does not participate in liquid 
flow. Consequently, the transfer of water between fractures and the rock matrix is limited, thereby reducing the effects of matrix diffusion — a key mechanism for removing radionuclides from advective transport in fractures (Neretnieks, 1993).

The current conceptual model of Yucca Mountain assumes that fracture flow paths are dispersed rather than focused (Liu et al., 1998; Bodvarsson et al., 1999, 2000), and that the number of fractures transmitting water is on the order of 1 every $10 \mathrm{~m}$. Data supporting this assumption include the relatively uniform average matrix saturations (about 85\%) for the RHH units (Flint, 1998), the small variability in in situ water-potential measurements for different boreholes within the Topopah Spring Tuff (Rousseau et al., 1997), and the fairly uniform temperatures within this unit (Bodvarsson et al., 1999; Rousseau et al., 1999). Further evidence supporting a $10 \mathrm{~m}$ spacing of fractures carrying water comes from calcite coatings (indicating water flow) observed in approximately $8 \%$ of fractures within the welded units (Sweetkind et al., 1997b).

To date, analyses of fracture hydraulic properties have not explored the potential effects of small-scale fractures (those less than about $1 \mathrm{~m}$ in length). It is unknown whether or not these small structures contribute significantly to ambient flow, but as discussed below, they may be important to transport and coupled thermal-hydrological processes.

\section{Summary of Fracture Characteristics within the Potential RHH}

Fractures at Yucca Mountain have been described by their physical geometric characteristics as well as by their potential hydraulic characteristics. Fracture geometry data come from a variety of surface and underground mapping studies, while estimates of fracture hydrologic properties have been derived from in situ field testing and observation of system response to both natural and artificial perturbations. Both geometric and hydrologic data on fractures aid in the 
development of conceptual models (and subsequent numerical models) describing flow and transport processes within the UZ at Yucca Mountain.

\subsection{Geometric Characteristics}

Fracture geometric characteristics at Yucca Mountain have been determined based on data collected from underground excavations, borehole structure logs, and surface (outcrop, pavement) mapping studies. By far the best and most abundant data describing fractures at Yucca Mountain come from Full-Periphery Geologic Maps (FPGMs) and Detailed Line Surveys (DLS) of the underground tunnels: the Exploratory Studies Facility (ESF) and the Cross-Block Drift (CBD). The FPGMs provide fracture location and orientation (i. e., strike and dip) data, while the DLS data set contains information about fracture location, orientation, spacing, trace length, aperture, roughness, and mineralization. Spatial and lithologic variability in fracture characteristics can be seen in these data sets. Approximately 36,000 fractures are included in the FPGMs, while the DLS data set contains statistics on about 20,000 individual fractures (NiederWestermann, 2000). Fracture data from boreholes and surface mapping studies contribute only a small amount to the overall body of fracture information and have much greater limitations as to their representativeness; therefore, they are not evaluated in this paper. Because of their vertical orientation, boreholes greatly underestimate the number of steeply dipping fractures, which comprise the majority of all fractures at Yucca Mountain. Fractures near the land surface may not be representative of those deeper in the subsurface because of the different field stresses exerted on the rocks. The minimal confining stresses at and near the land surface enhance the development of fractures. Physical instability of fractures in the upper vadose zone (due to wetting and drying cycles) may lead to rapid variations in flow rates. This has been reported for vadose-zone chalk under arid conditions (Weisbrod et al., 2000). Deeper in the UZ, at the 
potential repository horizon, these near-surface transient events are likely to play a minor role (Liu, 2000), and fracture geometry may be considered constant.

A statistical analysis of fracture characteristics based on the FPGM and DLS data sets was performed by Nieder-Westermann $(1998,2000)$. A summary of fracture characteristics (i.e., orientation, spacing, and trace length) for each of the RHH units is provided in Table 1, with graphical representation (joint rosettes and projection of major joint sets) provided in Figure 3. These statistics are based on fractures with trace lengths equal to or greater than 1 meter. To date, very limited information has been collected on smaller-scale fractures. A comprehensive study covering a statistically significant portion of the tunnels could greatly impact these results, particularly regarding trace-length distribution. Included in Table 1 for each unit within the RHH are fractures that could not be categorized by a systematic joint set. These nonsystematic, or "unassigned," fractures make up a significant proportion (22-45\%) of the total fractures mapped within each unit. Systematic joint sets can be used to estimate matrix block sizes, although consideration of nonsystematic fractures and small-scale fractures is needed for a more realistic assessment of matrix blocks. Figure 4 schematically illustrates a matrix block bounded by systematic joint sets, with the interior of the block containing nonsystematic fractures.

Based on the joint-set information provided in Table 1, the Tptpmn appears on average to have the smallest matrix blocks, while the Tptpll appears to have the largest matrix blocks. However, this may not be representative of the natural system because of sampling biases. For instance, about $80 \%$ of all fractures mapped in the RHH belong to the Tptpmn unit because this unit has the greatest exposure area in the ESF and CBD. As a result of relatively limited exposure, the Tptpul, Tptpll, and Tptpln represent only 13\%, 5\%, and 2\%, respectively, of the RHH fracture data set. Trace length is another important measurement bias, as discussed 
previously. Cavities within the Tptpll commonly prevent propagation of medium-to-long-tracelength fractures, yet small fractures are abundant within the unit. Because fractures less than $1 \mathrm{~m}$ in length are excluded from this analysis, many of the fractures within the Tptpll have not been taken into account. Furthermore, a high percentage (greater than 40\%) of fractures mapped in the Tptpll cannot be assigned to specific joint sets. These "unassigned" fractures could further reduce matrix block size.

Mapping of fractures down to $0.3 \mathrm{~m}$ in length has been done in selected intervals of the ESF, primarily along the North Ramp and systematically at 500-m intervals throughout the remaining ESF. Mapping down to the centimeter scale has been performed at six targeted locations in the CBD. Aside from these six areas, only fractures with trace lengths greater than or equal to $1 \mathrm{~m}$ were included in the FPGMs and DLS studies of the CBD.

As illustrated in Figure 5, the data indicate that small fractures comprise the majority of all fractures at Yucca Mountain, yet rigorous statistical analyses and conceptual flow models incorporating small fractures are lacking. This is partly because detailed, small-scale mapping of the entire tunnel system is impractical, but also partly because small fractures were not thought to contribute significantly to flow and transport processes. In light of recent in situ field testing in the Tptpll (discussed below), small trace-length fractures may have much greater significance to flow and transport in this unit than previously believed.

While acknowledging the biases within the fracture geometric data set, this information provides a starting point from which to evaluate fracture connectivity and spatial variability, both of which are important for determining potential flow pathways for air, liquid, and vapor.

Data from the DLS also include fracture aperture distributions; however, these measurements do not provide relevant information for flow and transport modeling because fracture apertures 
observable in the field cannot be measured below about 200 microns. Yet it is believed that the fracture apertures important for capillary-driven flow are often less than 200 microns. More important to flow modeling studies are "effective hydraulic apertures" (those that govern flow), which cannot be derived from the wide variation of apertures measured in the field, but rather require a combination of in situ testing (e.g., air-injection/permeability measurements) and fracture density information (Liu et al., 2000). For these reasons, fracture aperture distributions from field observations are typically not used in hydrologic models.

\subsection{Hydrologic Characteristics}

Understanding the movement of water, gas, and heat through Yucca Mountain's UZ — which occurs in the RHH units mainly through fractures — has been the goal of numerous field and numerical modeling studies designed to evaluate the performance of a potential repository. Among the most important hydrologic characteristics of fracture networks needed as model input to assess the behavior of the flow system are fracture connectivity, fracture permeability, fracture porosity, and fracture-matrix interaction.

\section{Fracture Connectivity}

Fracture-network connectivity determines potential flow pathways for air, liquid, and vapor, and is a function of fracture orientation, spacing (intensity), and size (trace length). At Yucca Mountain, the total number of fractures is estimated to be on the order of $10^{9}$ (Doughty, 1999); however, the proportion of connected fracture networks actively participating in ambient liquid flow, transport, and coupled thermal-hydrological processes varies.

Mountain-scale (i.e., greater than 100-m scale) fracture connectivity has been determined in part by observation of pneumatic pressure responses deep within the mountain to changes in 
surface barometric pressure. Because of low matrix porosities and permeabilities within densely welded tuffs, fractures are the principal pathways through which barometric pressure changes are transmitted. In situ pneumatic-pressure monitoring data collected within the Topopah Spring Tuff show very little attenuation and lag of the atmospheric-pressure signal across the unit, indicating that fracture networks are globally well connected within both nonlithophysal and lithophysal units, and flow is preferentially vertical (Rousseau et al., 1999).

Fracture-network connectivity has also been determined, at a submountain scale (i.e., drift scale), through single- and crosshole analyses of air-injection tests conducted in alcoves and niches within the ESF and CBD. Results of these tests indicate that fracture networks are well connected within the moderately to densely welded rocks currently selected to host the potential repository (Wang et al., 2001).

\section{Fracture Permeability}

The distribution of effective liquid permeability within the unsaturated, fractured rock at Yucca Mountain has important implications for potential repository performance. Because of the large variability in fracture attributes (e.g., connectivity, orientation, length, aperture, mineral infilling), direct measurements of fracture hydraulic properties are not easily obtained (Bandurraga and Bodvarsson, 1999). In general, estimates of liquid permeability are derived from measurements of pneumatic pressure response to either natural barometric-pressure changes or artificial air injection into discrete intervals of rock (LeCain, 1997, 1998; Rousseau et al., 1999; Wang et al., 2001). Within the welded tuffs at Yucca Mountain, which have very low matrix porosity and permeability, changes in pressure reflect the transmissivity and connectivity of fracture networks. 
At the mountain scale, estimates of permeability calculated from pneumatic-pressure responses to barometric-pressure changes range from about $10^{-11} \mathrm{~m}^{2}$ to $5 \times 10^{-11} \mathrm{~m}^{2}$ for the welded portions of the Topopah Spring Tuff (Rousseau et al., 1999). Permeability estimates obtained from air-injection tests in surface-based vertical boreholes are at least an order of magnitude less than values derived from atmospheric changes because the pneumatic disturbance is applied over a smaller scale (packer lengths are approximately $4 \mathrm{~m}$ ) (Rousseau et al., 1999; Liu et al., 2000). Studies by Neuman (1994) and Bodvarsson et al. (2001) show that mean permeability decreases as the scale of the measurement decreases. Underground air-injection tests within Alcove 5 of the ESF are conducted over 1 to $12 \mathrm{~m}$ intervals, which is on the same relative scale as the tests performed in the surface-based vertical boreholes. Average fracture permeabilities derived from air-injection testing are summarized in Table 2 for each of the RHH units.

The uncertainty and variability of fracture permeabilities for the stratigraphic layers are reflected by the standard deviations reported in Table 2 . These standard deviations would result in $95 \%$ confidence intervals covering three orders of magnitude, even for the units that had a large number of sampled intervals. The data show that fracture permeabilities are highly variable, which is consistent with the observed geologic heterogeneity in the Topopah Spring Tuff.

Additional air-permeability data on a scale of one-foot intervals are also available from airinjection testing in ESF niches in the Tptpmn unit (Wang et al., 2001). The air-permeability data from the relatively small-scale niche studies are generally an order of magnitude lower than the values from surface-based vertical boreholes and may not be representative of a larger-scale effective permeability (Liu et al., 2000). 
In general, air-injection data indicate that the Tptpll is more permeable than the Tptpmn (Wang et al., 2001). The greater permeability in the Tptpll may be the result of interconnected cavities, or it may be attributed to many small well-connected fractures. Most likely it is a combination of the two. Results of liquid-release testing involving injection of colored dye into testbeds within the Tptpmn show a strong component of downward (i.e., gravity-driven) flow as evidenced by the asymmetrical dye pattern observed after excavation. A similar experiment involving injection of water containing dye has been carried out in the Tptpll. Preliminary results suggest the presence of strong capillary (dispersive) forces because the dye pattern was more symmetrically distributed around the injection point within the Tptpll (Wang et al., 2001). Simulated drift-seepage studies performed by Finsterle et al. (2000) indicate that seepage is less likely to occur in the Tptpll than in the Tptpmn because of the combination of intense fracturing (establishing good connectivity and higher permeability) and strong capillarity, which allows water to be diverted around the drift opening. These results support a conceptual model for fracture flow in which gravity-driven fracture flow occurs primarily in the larger, high-angle fractures of the Tptpmn, while capillary forces within the smaller but well-connected fractures of the Tptpll allow for significant lateral dispersion.

\section{Fracture Porosity}

Fracture porosity is the effective porosity of fractures in which fluid flow and solute transport take place (Liu et al., 2000). Compared with matrix porosity, fracture porosity is very small, yet because fractures are key pathways, the volume of space they occupy has important ramifications for flow and transport. A combination of fracture porosity data derived from gas tracer tests in the ESF and porosity estimates based on the geometry of fracture networks has been used to develop fracture porosities for modeling studies of the UZ at Yucca Mountain. Since gas-tracer 
travel times through the fractured rocks are directly related to the storage of the corresponding fracture networks, analyses of tracer data can provide reliable estimates of fracture porosity if matrix diffusion is negligible (Liu et al., 2000). The porosities estimated from the tracer tests range from about 0.006 to 0.02 (Y.W. Tsang, personal comm.; Liu et al., 2000). These values are consistent with those estimated from the ESF seepage test results described in Finsterle et al. (2000). Gas tracer tests conducted by LeCain et al. (1998) yielded slightly higher porosity values of 0.03 to 0.07 for fractures associated with the Ghost Dance fault. Previous estimates of fracture porosity based solely on fracture mapping data are approximately two orders of magnitude less than the average value of 0.01 obtained from the studies described above (Bodvarsson et al., 2000). Currently, all fracture porosity studies have been carried out in the Tptpmn unit of the Topopah Spring Tuff.

Modeling predictions of drift-scale seepage and ambient mountain-scale flow have proven to be insensitive to fracture porosities because of assumed steady-state conditions (Finsterle et al., 2000; Y-.S. Wu, personal comm.). However, fracture porosity is a critical parameter needed to model potential radionuclide transport and coupled thermal-hydrological-chemical (THC) processes. Estimated groundwater travel times between the potential repository horizon and the water table are shorter when smaller fracture porosities are used because of less storage potential in the fracture networks (Y-.S. Wu, personal comm.). As for THC processes, mineral precipitation along fracture walls reduces porosity and may lead to fracture sealing, which could significantly impact flow (Sonnenthal and Spycher, 2001). Consequently, the initial fracture porosity has important implications for whether or not fractures will become sealed.

\section{Fracture-Matrix Interaction}


Flow and transport models need field data for partitioning UZ flux into a fast fracture-flow component and a slow matrix-flow component within the Topopah Spring Tuff. This partitioning is controlled by the interacting surface area between fractures and the rock matrix, termed fracture-matrix interaction. Fracture-matrix interaction refers to flow and transport between fractures and the rock matrix.

Under ambient conditions, fracture-matrix interaction is likely to be limited within welded units at Yucca Mountain, as mentioned above, for reasons summarized in Liu et al. (1998), Bodvarsson et al. (1999), and Liu (2000). Key lines of evidence supporting limited fracturematrix interaction include geochemical analyses of water samples. Chloride concentration data indicate that perched water is recharged mainly from fracture water, with a small degree of interaction with matrix water (Yang et al., 1996). The small degree of interaction between fractures and matrix at locations associated with specific geologic features is also suggested by the presence of bomb-pulse chlorine-36 (Fabryka-Martin et al., 1998) at the potential repository level in the ESF. In addition to geochemical analyses, the relatively large in situ water potentials (greater than about -3 bars) observed in surface-based vertical boreholes indicate that the rock matrix of the Topopah Spring Tuff is sufficiently wet (at least near fractures) that should water flow through the fractures, it would undergo little imbibition by the rock matrix, because of the low matrix permeability and small water-potential gradients across the fracture-matrix interface (Rousseau et al., 1997).

As described later in this paper, the amount of fracture-matrix interaction may be greatly enhanced in the near-drift environment under thermally perturbed conditions associated with radioactive decay. 


\section{Fracture Data Relevant to Process Models}

The fracture data summarized above lend themselves to the development of conceptual models describing the contribution of fractures to a variety of processes, such as flow, transport, and thermal-hydrological phenomena. Each process has its own conceptual model that is affected not only by the geometric and hydraulic characteristics of fractures, but by boundary conditions (e.g., infiltration, percolation rate) and source terms (e.g., heat). These latter conditions determine which fractures participate in a given process. The scale of the process also determines the number and size of relevant fractures. In the following subsections, we identify the relevant fracture data from the RHH needed as input to three different process models used to assess the behavior of the UZ at Yucca Mountain.

\subsection{Mountain-Scale Ambient Liquid Flow Models}

Ambient liquid flow models for the UZ of Yucca Mountain have been developed to simulate mountain-scale hydrological conditions for the present climate and to predict future system changes to climate-related perturbations. Recent flow models (Wu et al., 1999; Bodvarsson et al., 2000) estimate spatially variable percolation flux through the UZ and predict groundwater travel times and flow paths from the potential repository to the water table. These flow models also investigate interactions between fractures and the rock matrix within and below the potential repository horizon.

Under the present-day low infiltration rates, not all connected fractures transmit water in the UZ. Liu et al. (1998) estimate the number to be less than $30 \%$. Only medium to large tracelength fractures that actively contribute to flow are believed to be significant because these fractures have a higher probability of intersecting other fractures and forming a network. Smaller fractures will typically have lower permeability, smaller apertures, and greater capillary 
pressure, and may therefore be more inclined to store water than contribute to mountain-scale fracture flow. Though this assumption may be reasonable for the Tptpmn and, by analogy, the Tptpln, which have networks of moderately coarse fractures largely uninterrupted by cavities, the predominance of small, well-connected fractures within the Tptpll will require consideration and possible inclusion of smaller trace-length fractures into numerical models. As previously stated, preliminary field data suggest that smaller fractures in the Tptpll have a significant impact on flow by dispersing flow through capillary mechanisms (Wang et al., 2001).

Of those fractures that carry water, the surface area of the rock matrix in contact with water flowing in fractures will be a fraction of the total matrix surface area adjacent to the fracture and a function of saturation (Liu et al., 1998). This "effective" fracture-matrix interface area is an important input variable to numerical models of unsaturated flow because it physically reduces the amount of flux between fractures and matrix. Because of the large variability in fracture characteristics at Yucca Mountain, the distribution of effective fracture-matrix contact area cannot be directly measured. Total fracture-matrix contact area is estimated using fracture spacing and trace length, and a fracture-matrix interface reduction factor is applied based on the conditions of saturation.

Given the availability of data, for mountain-scale ambient liquid flow modeling, we believe the current modeling approach, which uses mapped data for coarse fractures (i.e., those equal to or greater than $1 \mathrm{~m}$ in trace length) to estimate fracture network characteristics within the $\mathrm{RHH}$ and which adjusts the fracture-matrix interface reduction variable to match observed field data, is appropriate. If small fractures contribute to large-scale flow, their effects can be accounted for by adjusting the fracture-matrix interface reduction variable. Nonetheless, additional studies and data collection efforts aimed at achieving a more statistically representative fracture data set (one 
that includes small fractures) for the Tptpll could enhance confidence in model simulation results.

\subsection{Mountain-Scale Radionuclide-Transport Models}

The objectives of mountain-scale radionuclide-transport models have been to evaluate the movement of radioactive solutes and colloids from the potential repository horizon to the water table under a range of climate scenarios. Radionuclide-transport processes are closely tied to water flow behavior, because liquid water is considered the principal medium in which solutes and colloids are transported through the UZ. Described and modeled by Moridis et al. (2000), important radionuclide-transport processes in the UZ include advection, matrix diffusion, sorption, dispersion, and colloid-facilitated transport processes.

Advection within fractures is expected to dominate transport behavior in the welded units, such as those in the RHH, because of high fracture permeability, small fracture pore volume, and limited contact between the radionuclide-carrying liquid phase and the matrix (Moridis et al., 2000). Because flow velocity in the welded-tuff matrix is much slower than in fractures, transfer of radionuclides from fractures to matrix would significantly retard the overall transport of radionuclides. Where fracture flow is dominant, an important mechanism contributing to retardation of radionuclide transport may be matrix diffusion (Neretnieks, 1993; Moridis et al., 2000; Bodvarsson et al., 2001). The significance of matrix diffusion depends, in part, on such factors as the effective contact area between fractures and matrix, molecular diffusion coefficient, and fracture-network characteristics. Because of limited fracture-matrix interaction under ambient flow conditions, only a small portion of the geometric contact area between fractures and matrix is available for matrix diffusion, thus limiting the retardation effect of the matrix. However, the existence of smaller fractures becomes important for transport because 
they enhance the storage capacity of the rock. They also penetrate matrix blocks and may exhibit large capillary forces, thus increasing the fracture-matrix interface area, which may enhance matrix diffusion. This may be of particular significance within the Tptpll with its predominance of small fractures.

Radionuclide transport in the UZ at Yucca Mountain may be facilitated by colloidal transport processes, as suggested by analyses of radionuclides in groundwater samples from the Nevada Test Site (Kersting et al., 1999). Colloids are particles that are small enough to become suspended (and thus transportable) in a liquid. They can interact with radionuclides through sorption mechanisms. Unlike sorption of radionuclides to the rock matrix, however, radionuclides sorbed on colloids are potentially mobile. Therefore, colloids can facilitate radionuclide transport through the $\mathrm{UZ}$ at a faster rate than the aqueous phase alone (de Marsily, 1986). Colloid particles themselves are not expected to experience any significant matrix diffusion because of their low diffusion coefficients. Therefore, transport models based on solute migration alone may be inappropriate to describe radionuclide movement.

Because the patterns of flow and transport are expected to be similar under ambient conditions, the current approach for modeling mountain-scale transport is the same as the approach described above for flow modeling. This approach may be insufficient because smallscale fractures penetrate matrix blocks (most notably in the Tptpll unit), thereby increasing storage capacity and potentially enhancing matrix diffusion. Those small fractures connected to larger "active" fractures may be significant to radionuclide-transport calculations and, thus, deserve additional consideration. This could affect determination and use of the fracture-matrix interaction variable. 


\subsection{Coupled Thermal-Hydrological (TH) Models}

If a repository is constructed at Yucca Mountain, the high-level radioactive waste will emit a significant amount of heat as a result of radioactive decay. This heat, in turn, will affect the hydrological, mechanical, and chemical conditions in the near-drift environment. In this paper, we focus mainly on coupled thermal-hydrological (TH) effects.

Conceptually, as discussed in Tsang and Birkholzer (1999), when temperatures increase sufficiently around the waste packages, pore water (mostly in matrix blocks) will boil and vaporize. The bulk of the vapor generated will migrate into the fractures, where it will be driven away from the repository drifts by gas-pressure gradients, thus creating a dryout zone. When the vapor encounters cooler rock away from the drifts, it will condense, and saturations will increase locally in all fractures. Part of the condensate may then imbibe into the matrix. Some of the condensate will remain in the fractures, become mobile, and drain around the drift opening. Directly above the drift, condensate may flow through fractures back toward the boiling region (dryout zone). This conceptualization is schematically illustrated in Figure 6.

The reflux of liquid water through fractures back into the dryout zone could impact repository performance if flow focusing occurs. Drainage of condensate through fractures under the influence of gravity may be sufficient to prevent temperatures from locally rising above the boiling point and may result in drift seepage (Tsang and Birkholzer, 1999). However, there is an alternative conceptualization. Because of capillary-barrier effects, a significant amount of the condensed water may be laterally diverted through fracture networks around the drift opening (Finsterle et al., 2000; Bodvarsson et al., 2000). The potential for flow focusing and seepage may be further reduced because of the relatively even distribution of condensate expected above a drift and the short distance over which condensed water has to focus within the boiling region 
before encountering the drift opening. Instead, distributed condensation above a drift may be more likely to boil off upon reentering the boiling region. Some portion of this water may be laterally diverted around the drift each time the boiling/condensation cycle occurs, so that with time, the amount of water available for seepage will decrease. Both with distance away from the drift and with time, ambient conditions will prevail as heat output from the drift decreases and becomes small enough not to affect the liquid flow field.

In summary, all fractures at all scales in the near-drift environment are important to $\mathrm{TH}$ processes. For modeling purposes, we recommend using all mapped fracture data (including data on smaller fractures, when available) and using the full fracture-matrix interface area in the condensation zone because local saturations will increase everywhere within this region. Furthermore, for modeling near-drift environments, post-excavation permeabilities are more appropriate for use than are pre-excavation permeabilities because tunnel-excavation activities have been shown to enhance the near-drift permeability field (Wang et al., 2001).

Similar to TH phenomena, thermal-hydrological-mechanical (THM) and thermalhydrological-chemical (THC) processes will be limited in their spatial extent to the near-drift environment (i.e., within a few tens of meters of the drift), where the greatest temperature changes will occur. THM and THC processes affect, and are most directly affected by, fracture aperture and porosity. Observations made during drift-scale heater testing at Yucca Mountain noted only modest reductions in fracture permeability (Tsang and Birkholzer, 1999), thus suggesting that THM effects are likely to be small. Model results from drift-scale THC simulations indicate that changes in fracture porosity and permeability are small and have a little effect on flow and transport (Sonnenthal and Spycher, 2001). The blind THC model predictions of water chemistry $(\mathrm{pH}), \mathrm{CO}_{2}$ concentrations, and other chemical factors have compared well 
with subsequent observations from actual drift-scale testing, providing validation of the THC model.

\section{Summary and Conclusions}

Studies designed to characterize fracture geometry and fracture hydrologic properties have yielded a large body of information that has been used to shape our understanding of how liquid, air, and heat move through the unsaturated tuffs at Yucca Mountain. Fracture mapping has provided statistical information about fracture orientations, spacing, and trace length needed to establish a basis for determining the distribution of fracture hydraulic characteristics obtained from in situ field testing. To produce viable simulation results, numerical modeling studies used to evaluate flow, transport, and coupled TH, THM, and THC behavior in the UZ of Yucca Mountain require appropriate fracture input data. In many cases, only a subset of the entire fracture data set is relevant to a particular process.

Based on the current (draft) design layout for the potential repository, the majority of emplacement drifts would be constructed within the lower lithophysal zone (Tptpll) of the Topopah Spring Tuff, with a relatively small percentage of drifts located in the middle and lower nonlithophysal zones (Tptpmn and Tptpln, respectively). Within each of these moderately to densely welded potential repository units, fractures are the primary pathways for movement of liquid and air. Under ambient conditions characterized by very little infiltration, only a small proportion of all fractures actively carry water and, within these active fractures, flow focusing is believed to occur because of such mechanisms as fracture heterogeneity and gravitational instability (Nicholl et al., 1994; Liu et al., 1998). As a result, very little flow between fractures and matrix is expected under ambient conditions. 
Results of fracture mapping and in situ testing and observation confirm that fractures form well-connected networks in the potential repository host rocks; however, the distribution of fracture characteristics is complex and heterogeneous. Fracturing within the Tptpll unit is markedly different from the fracturing observed the Tptpmn and Tptpln units, and most likely reflects the abundance of cavities. Vertical, gravity-driven flow is typical along steeply dipping fractures in the Tptpmn unit, while the abundance of small fractures with strong capillarity within the Tptpll may promote significant lateral redistribution of water (Wang et al., 2001).

Implementation of appropriate fracture data into numerical models requires knowledge of the process being investigated. To simulate ambient flow and transport conditions on a mountain scale, only information about those fractures that contribute to global flow and transport is needed. This will be a very small portion of the total number of fractures present in the UZ, but the number of fractures and their characteristics must be statistically representative of the processes involved. For instance, smaller fractures, which are not expected to contribute to global flow, may be relevant to transport phenomena. To model thermal-hydrological processes, a drift-scale approach may be more appropriate to target the affected environment. Although smaller than mountain-scale models, drift-scale TH models require consideration of a much greater number of fractures, because in certain areas of the domain, such as the condensation zone, all fractures at all scales participate in the thermodynamic system, resulting from vapor transport. Furthermore, the enhanced fracture permeability immediately surrounding drifts caused by excavation activities should be taken into account.

Several important limitations of the available fracture data set for Yucca Mountain must be acknowledged before applying this information to modeling studies. First, most fracture data come from the Tptpmn. In light of the observed geologic heterogeneity (e.g., fracturing and 
cavity abundance) within the RHH and order-of-magnitude or greater differences in air permeabilities for the Tptpmn and Tptpll units, use of Tptpmn as an analogy to the other RHH units may not be appropriate. Second, the number of fractures transmitting water is difficult to estimate. A value of 1 fracture per $10 \mathrm{~m}$ is only an order-of-magnitude estimate based on a number of indirect observations, such as the relatively uniform matrix saturation and moisturetension data for the entire RHH, and the distribution of calcite coatings on fracture walls. Again, these observations were made almost exclusively within the Tptpmn and may have limited application to the other RHH units. Nevertheless, integration of fracture data at different scales from geologic mapping studies with data from field hydrological-testing activities helps constrain uncertainty in process-model calculations. Collection and analyses of additional, statistically representative data regarding small fractures can also improve confidence in our understanding of the fractured flow system in the UZ of Yucca Mountain.

\section{Acknowledgments}

The authors thank H. H. Liu, J. Gauthier, and N. Weisbrod for their critical and careful reviews of this paper. This work was supported by the Director, Office of Civilian Radioactive Waste Management, U.S. Department of Energy, through Memorandum Purchase Order EA9013MC5X between Bechtel SAIC Company, LLC and the Ernest Orlando Lawrence Berkeley National Laboratory (Berkeley Lab). The support is provided to Berkeley Lab through the U.S. Department of Energy Contract No. DE-AC03-76SF00098.

\section{References}

Albin, A.L., Singleton, W.L., Moyer, T.C., Lee, A.C., Lung, R.C., Eatman, G.L.W., and Barr, D.L., 1997. Geology of the Main Drift-Station 28+00 to 55+00, Exploratory Studies Facility. Yucca Mountain Project, Yucca Mountain, Nevada: Report by the U.S. Bureau of Reclamation 
and U.S. Geological Survey to the U.S. Department of Energy. Denver, Colorado: U.S. Geological Survey.

Bandurraga, T.M. and Bodvarsson, G.S., 1999. Calibrating Hydrogeologic Parameters for the 3D Site-Scale Unsaturated Zone Model of Yucca Mountain, Nevada. J. Contam. Hydrol., 38 (13): $25-46$.

Barr, D.L., Moyer, T.C., Singleton, W.L., Albin, A.L., Lung, R.C., Lee, A.C., Beason, S.C., and Eatman, G.L.W., 1996. Geology of the North Ramp-Stations 4+00 to 28+00, Exploratory Studies Facility, Yucca Mountain Project. Yucca Mountain, Nevada: Report by the U.S. Bureau of Reclamation and U.S. Geological Survey to the U.S. Department of Energy. Denver, Colorado: U.S. Geological Survey.

Barton, C.C., Larsen, E., Page, W.R., and Howard, T.M., 1993. Characterizing Fractured Rock for Fluid-Flow, Geomechanical, and Paleostress Modeling: Methods and Preliminary Results from Yucca Mountain, Nevada. Open-File Report 93-269. Denver, Colorado: U.S. Geological Survey.

Bodvarsson, G.S., Ahlers, C.F., Cushey, M., Dove, F.H., Finsterle, S.A., Haukwa, C.B., Hinds, J., Ho, C.K., Houseworth, J., Hu, Q., Liu, H.H., Pendleton, M., Sonnenthal, E.L., Unger, A.J., Wang, J.S.Y., Wilson, M., and Wu, Y.-S., 2000. Unsaturated Zone Flow and Transport Model Process Model Report, TDR-NBS-HS-000002 Rev 00. Civilian Radioactive Waste Management System Management \& Operating Contractor (CRWMS M\&O): Las Vegas, Nevada.

Bodvarsson, G.S., Boyle, W., Patterson, R., and Williams, D., 1999. Overview of Scientific Investigations at Yucca Mountain - the Potential Repository for High-Level Nuclear Waste. J. Contam. Hydrol., 38 (1-3): 3-24.

Bodvarsson, G.S., Liu, H.H., Ahlers, C.F., Wu, Y-.S., and Sonnenthal, E., 2001.

"Parameterization and Upscaling in Modeling Flow and Transport in the Unsaturated Zone of Yucca Mountain," in Conceptual Models of Flow and Transport in the Fractured Vadose Zone. National Research Council, Washington, D.C.: National Academy Press, pp. 335-365.

Buesch, D.C., Spengler, R.W., Moyer, T.C., and Geslin, J.K., 1996. Proposed Stratigraphic Nomenclature and Macroscopic Identification of Lithostratigraphic Units of the Paintbrush Group Exposed at Yucca Mountain, Nevada. U.S. Geological Survey Open File Report 94-469. Denver, Colorado: U.S. Geological Survey.

de Marsily, G., 1986. Quantitative Hydrology, Groundwater Hydrology for Engineers. Orlando, Florida: Academic Press.

Doughty, C., 1999. Investigation of Conceptual and Numerical Approaches for Evaluating Moisture, Gas, Chemical, and Heat Transport in Fractured Unsaturated Rock. J. Contam. Hydrol., 38 (1-3): 69-106.

Fabryka-Martin, J.T., Wolfsberg, A.V., Roach, J.L., Levy, S.S., Winters, S.T., Wolfsberg, L.E., Elmore, D., and Sharma, P., 1998. "Distribution of Fast Hydrologic Paths in the Unsaturated 
Zone at Yucca Mountain.” Proceedings of the Eighth International Conference on High-Level Radioactive Waste Management, Las Vegas, Nevada, May 11-14, 1998, pp. 93-96. La Grange Park, Illinois: American Nuclear Society.

Finsterle, S., Trautz, R.C., and Ahlers, C.F., 2000. Seepage Calibration Model and Seepage Testing Data, MDL-NBS-HS-000004 Rev 01. CRWMS M\&O: Las Vegas, Nevada.

Flint, L.E., 1998. Characterization of Hydrogeologic Units Using Matrix Properties, Yucca Mountain, Nevada. Water-Resources Investigations Report 97-4243. Denver, Colorado: U.S. Geological Survey.

Flint, L.E., Flint, A.L., and Hevesi, J.A., 1994. "Shallow infiltration processes in arid watersheds." Proceedings of the Fifth International Conference on High-Level Radioactive Waste Management, Las Vegas, Nevada, May 22-26, 1994, pp. 2315-2322. La Grange Park, Illinois: American Nuclear Society.

Hevesi, J.A., 2000. Simulation of Net Infiltration for Modern and Potential Future Climates, ANL-NBS-HS-000032 Rev 00 ICN 01. CRWMS M\&O: Las Vegas, Nevada.

Kersting, A.B., Efurd, D.W., Finnegan, D.L., Rokop, D.J., Smith, D.K., and Thompson, J.L., 1999. Migration of Plutonium in Ground Water at the Nevada Test Site. Nature, 397 (6714), 5659.

LeCain, G.D., 1997. Air-Injection Testing in Vertical Boreholes in Welded and Nonwelded Tuff, Yucca Mountain, Nevada. Water-Resources Investigations Report 96-4262. Denver, Colorado: U.S. Geological Survey.

LeCain, G.D., 1998. Results from Air-Injection and Tracer Testing in the Upper Tiva Canyon, Bow Ridge Fault, and Upper Paintbrush Contact Alcoves of the Exploratory Studies Facility, August 1994 through July 1996, Yucca Mountain, Nevada. Water-Resources Investigations Report 98-4058. Denver, Colorado: U.S. Geological Survey.

LeCain, G.D., Fahy, M.F., Sweetkind, D.S., and Anna, L.O., 1998. "Underground Pneumatic and Tracer Testing in Fractured Tuff Associated with the Ghost Dance Fault, Yucca Mountain, Nevada: Part 1, Test Analysis Using and Equivalent Continuum Approach.” GSA Abstracts with Programs. GSA 1998 Annual Meeting, Oct 26-29, p. A-362. Toronto, Ontario: Geological Society of America.

Liu, H.H., 2000. Conceptual and Numerical Models for UZ Flow and Transport, MDL-NBS-HS000005 Rev 00. CRWMS M\&O: Las Vegas, Nevada.

Liu, H.H., Ahlers, C.F., and Cushey, M., 2000. Analyses of Hydrologic Properties Data, ANLNBS-HS-000002 Rev 00. CRWMS M\&O: Las Vegas, Nevada.

Liu, H.H., Doughty, C., and Bodvarsson, G.S., 1998. An Active Fracture Model for Unsaturated Flow and Transport in Fractured Rocks. Water Resources Research, 34 (10): 2633-2646. 
Marshall, B.D., Paces, J.B., Neymark, L.A., Whelan, J.F., Peterman, Z.E., 1998. “Secondary Minerals Record Past Percolation Flux at Yucca Mountain, Nevada." Proceedings of the Eighth International Conference on High Level Radioactive Waste Management, Las Vegas, Nevada, May 11-14, 1998, pp. 127-129. La Grange Park, Illinois: American Nuclear Society.

Mongano, G.S., Singleton, W.L., Moyer, T.C., Beason, S.C., Eatman, G.L.W., Albin, A.L., and Lung, R.C., 1999. Geology of the ECRB Cross Drift - Exploratory Studies Facility, Yucca Mountain Project, Yucca Mountain, Nevada. Report by the U.S. Bureau of Reclamation and U.S. Geological Survey to the U.S. Department of Energy. Denver, Colorado: U.S. Geological Survey.

Montazer, P. and Wilson, W.E., 1984. Conceptual Hydrologic Model of Flow in the Unsaturated Zone, Yucca Mountain, Nevada. Water Resources Investigations Report 84-4345. Denver, Colorado: U.S. Geological Survey.

Moridis, G.J, Hu, Q., and Bodvarsson, G.S., 2000. Modeling Studies of Radionuclide Transport in the Unsaturated Zone of Yucca Mountain, Nevada. Report LBNL-45870. Berkeley, California: Lawrence Berkeley National Laboratory.

Neretnieks, I., 1993. "Solute Transport in Fractured Rock-Applications to Radionuclide Waste Repositories," in Bear, J.; Tsang, C.F.; and de Marsilly, G. (Eds.), Flow and Contaminant Transport in Fractured Rock, pp. 39-127. San Diego, California: Academic Press.

Neuman, S.P., 1994. Generalized Scaling of Permeabilities: Validation and Effect of Support Scale. Geophysical Research Letters, 30 (21): 349-352.

Nicholl, M.J., Glass, R.J., and Wheatcraft, S.W., 1994. Gravity-Driven Infiltration Instability in Initially Dry Nonhorizontal Fractures. Water Resources Research, 30 (9): 2533-2546.

Nieder-Westermann, G.H., 2000. Fracture Geometry Analysis for the Stratigraphic Units of the Repository Host Horizon, ANL-EBS-GE-000006 Rev 00. CRWMS M\&O: Las Vegas, Nevada.

Nieder-Westermann, G.H., 1998. Geology of the Exploratory Studies Facility Topopah Spring Loop, BAB000000-01717-0200-00002 Rev 01. CRWMS M\&O: Las Vegas, Nevada.

Paces, J.B., Neymark, L.A., Marshall, B.D., Whelan, J.F., and Peterman, Z.E., 1998. "Inferences for Yucca Mountain Unsaturated-Zone Hydrology from Secondary Minerals." Proceedings of the Eighth International Conference on High-Level Radioactive Waste Management, Las Vegas, Nevada, May 11-14, 1998, pp. 36-39. La Grange Park, Illinois: American Nuclear Society.

Pruess, K., Faybishenko, B., and Bodvarsson, G.S., 1999. Alternative Concepts and Approaches for Modeling Flow and Transport in Thick Unsaturated Zones of Fractured Rocks. J. Contam. Hydrol., 38 (1-3): 281-322. 
Ross, C.S. and Smith, R.L., 1961. Ash-Flow Tuffs: Their Origin, Geologic Relations, and Identification. Professional Paper 366. Reston, Virginia: U.S. Geological Survey.

Rousseau, J.P., Kwicklis, E.M., and Gillies, D.C. (Eds.), 1999. Hydrogeology of the Unsaturated Zone, North Ramp Area of the Exploratory Studies Facility, Yucca Mountain, Nevada. WaterResources Investigations Report 98-4050. Denver, Colorado: U.S. Geological Survey.

Rousseau, J.P., Loskot, C.L., Thamir, F., and Lu, N., 1997. Results of Borehole Monitoring in the Unsaturated Zone Within the Main Drift Area of the Exploratory Studies Facility, Yucca Mountain, Nevada. U.S. Geological Survey Administrative Report to the U.S. Department of Energy. Denver, Colorado: U.S. Geological Survey.

Sawyer, D.A., Fleck, R.J., Lanphere, M.A., Warren, R.G., Broxton, D.E., and Hudson, M.R., 1994. "Episodic Caldera Volcanism in the Miocene, Southwestern Nevada Volcanic Field: Revised Stratigraphic Framework, $\mathrm{Ar}^{40} / \mathrm{Ar}^{39}$ Geochronology, and Implications for Magmatism and Extension." Geological Society of America Bulletin, 106, pp. 1304-1314. Boulder, Colorado: Geological Society of America.

Sonnenthal, E.L. and Spycher, N., 2001. Drift Scale Coupled Processes (DST, THC Seepage) Models, MDL-NBS-HS-000001 Rev 01 ICN 01. CRWMS M\&O: Las Vegas, Nevada.

Sweetkind, D.S., Anna, L.A., Coe, J., and Williams-Stroud, S., 1997a. "Characterizing the fracture network at Yucca Mountain, Nevada, Part 1. Integration of field data for numerical simulations," in Hoak, T.E., Blomquist, P.K, and Klawitter, A. (Eds.), Fractured Reservoirs: Descriptions, Predictions, and Applications. Rocky Mountain Association of Geologists 1996 Guidebook.

Sweetkind, D.S., Barr, D.L., Polacsek, D.K., and Anna, L.O., 1997b. Integrated Fracture Data in Support of Process Models, Yucca Mountain, Nevada. U.S. Geological Survey Administrative Report to the U.S. Department of Energy. Denver, Colorado: U.S. Geological Survey.

Tsang, Y.W. and Birkholzer, J.T., 1999. Predictions and Observations of the ThermalHydrological Conditions in the Single Heater Test. J. Contam. Hydrol., 38 (1-3): 385-425.

Wang, J.S.Y., Cook, P.J., Trautz, R.C., Hu, Q., and Salve, R., 2001. In Situ Field Testing of Processes, ANL-NBS-HS-000005 Rev 01. CRWMS M\&O: Las Vegas, Nevada.

Wang, J.S.Y., Trautz, R.C., Cook, P.J., Finsterle, S., James, A.L., and Birkholzer, J., 1999. Field Tests and Model Analyses of Seepage into Drifts. J. Contam. Hydrol., 38 (1-3): 323-347.

Weisbrod, N., Nativ, R., Adar, E.M., and Ronen, D., 2000. Salt Accumulation and Flushing in Unsaturated Fractures in an Arid Environment. Ground Water, 38 (3): 452-461.

Wu, Y-.S., Haukwa, C., and Bodvarsson, G.S., 1999. A Site-Scale Model for Fluid and Heat Flow in the Unsaturated Zone of Yucca Mountain, Nevada. J. Contam. Hydrol., 38 (1-3): 185215. 
Yang, I.C., Rattray, G.W., and Yu, P., 1996. Interpretation of Chemical and Isotopic Data from Boreholes in the Unsaturated Zone at Yucca Mountain. Water-Resources Investigations Report 96-4058. Denver, Colorado: U.S. Geological Survey. 
Figure Captions:

Figure 1. Location of Yucca Mountain.

Figure 2. Generalized lithostratigraphic column of the Paintbrush Group at Yucca Mountain, Nevada, showing the potential Repository Host Horizon (RHH) units emphasized in this paper (from Buesch et al., 1996).

Figure 3. Graphical illustration of joint rosettes and primary joint sets within units (a) Tptpul, (b) Tptpmn, (c) Tptpll, and (d) Tptpln. Developed using stereographic-projection techniques (from Nieder-Westermann, 2000).

Figure 4. Schematic of a matrix block defined by intersecting systematic joint sets, with the block interior displaying nonsystematic fracturing.

Figure 5. Trace-length distribution of all fractures longer than $0.3 \mathrm{~m}$ measured by the DLS over a $3 \mathrm{~km}$ length in the ESF (from Sweetkind et al., 1997a).

Figure 6. Conceptualization of the hydrological significance of fractures in the near-drift environment during the thermal period: (a) drift-scale overview, (b) detailed water movement above a drift. 


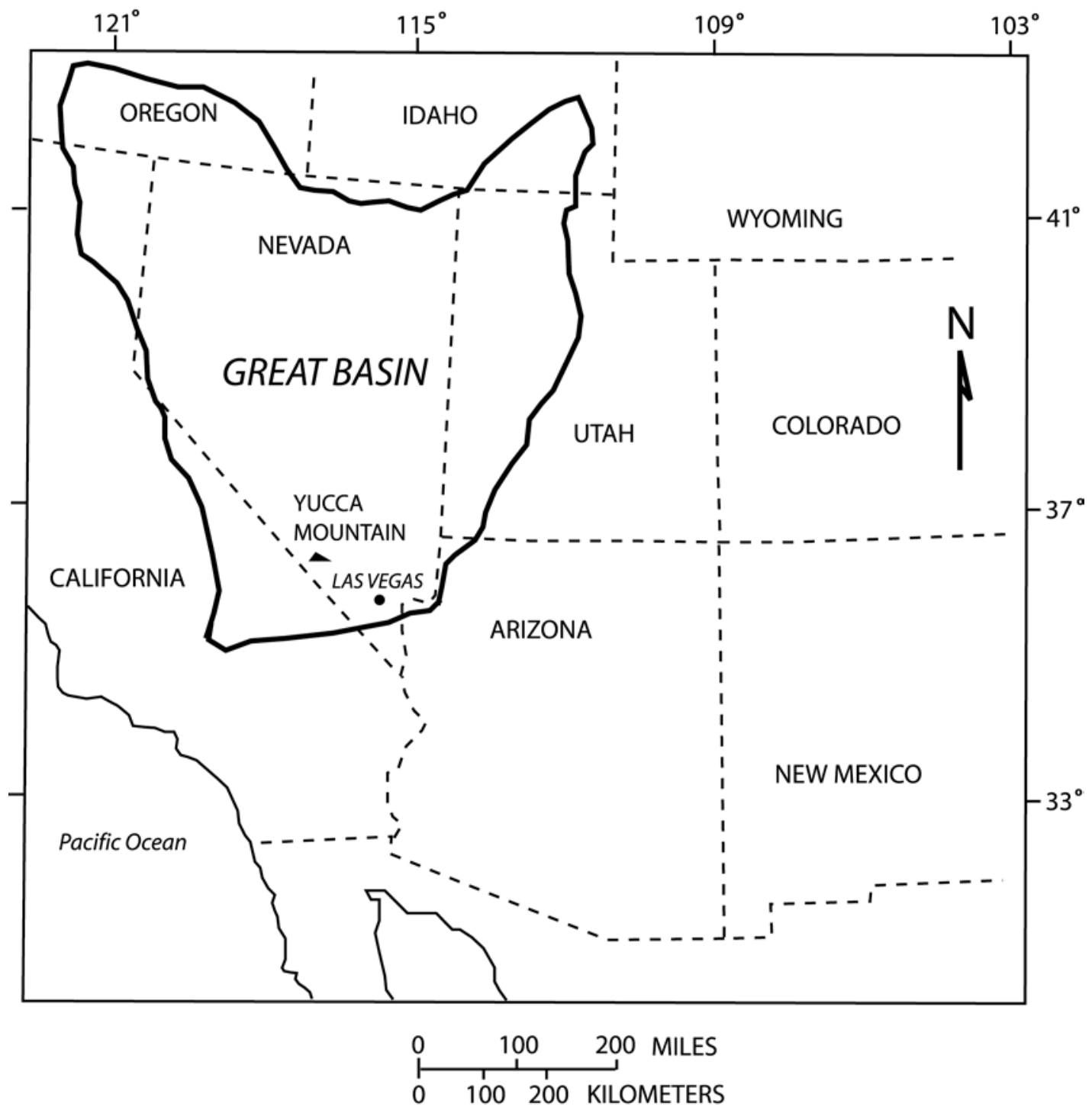

Figure 1. Location of Yucca Mountain. 


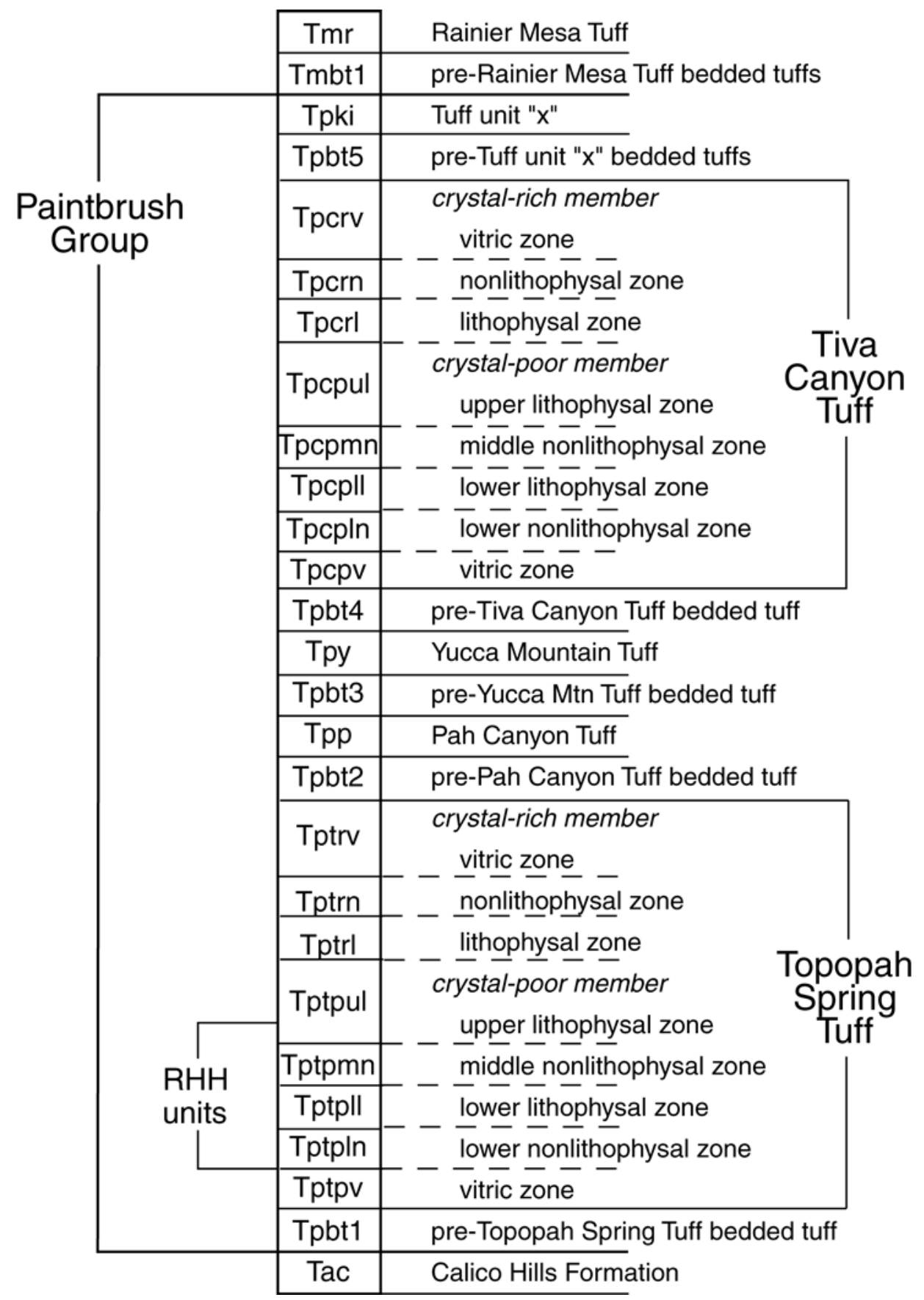

Figure 2. Generalized lithostratigraphic column of the Paintbrush Group at Yucca Mountain, Nevada, showing the potential Repository Host Horizon (RHH) units emphasized in this paper (from Buesch et al., 1996). 


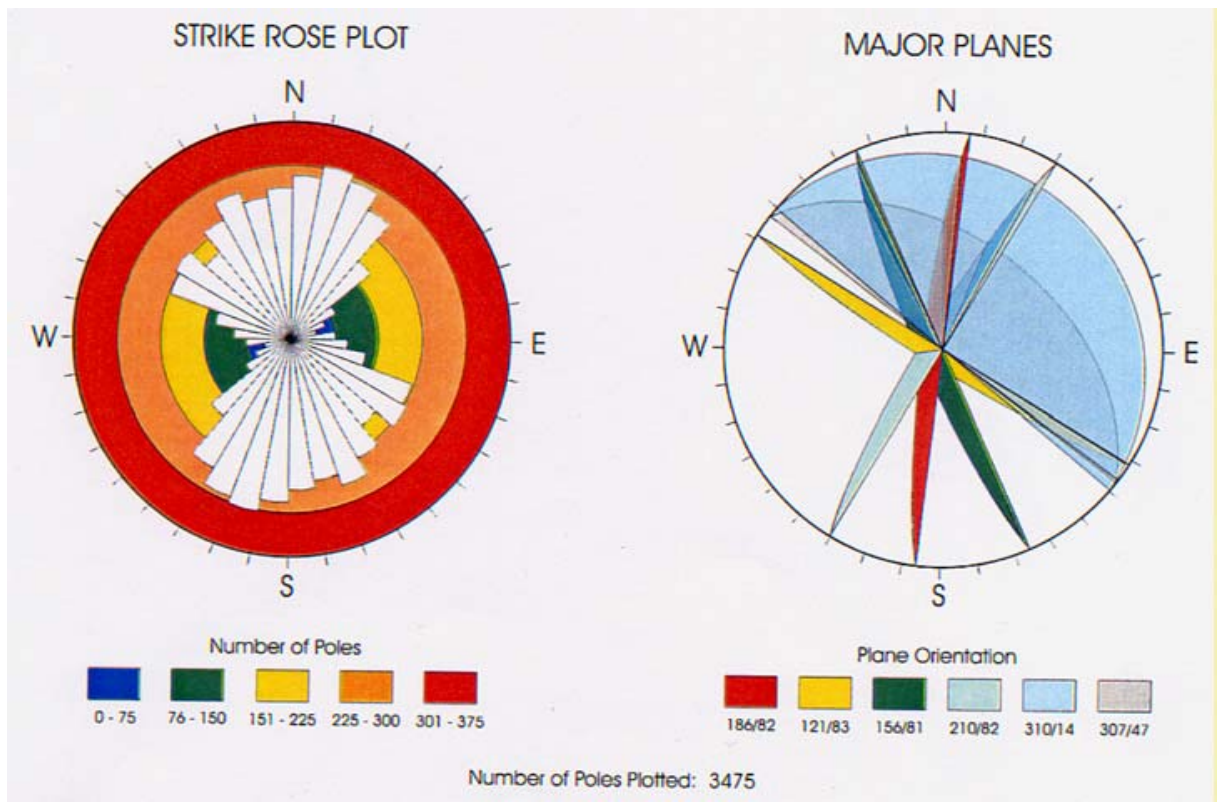

Figure 3a. Graphical illustration of joint rosettes and primary joint sets within units (a) Tptpul. Developed using stereographic-projection techniques (from NiederWestermann, 2000). 


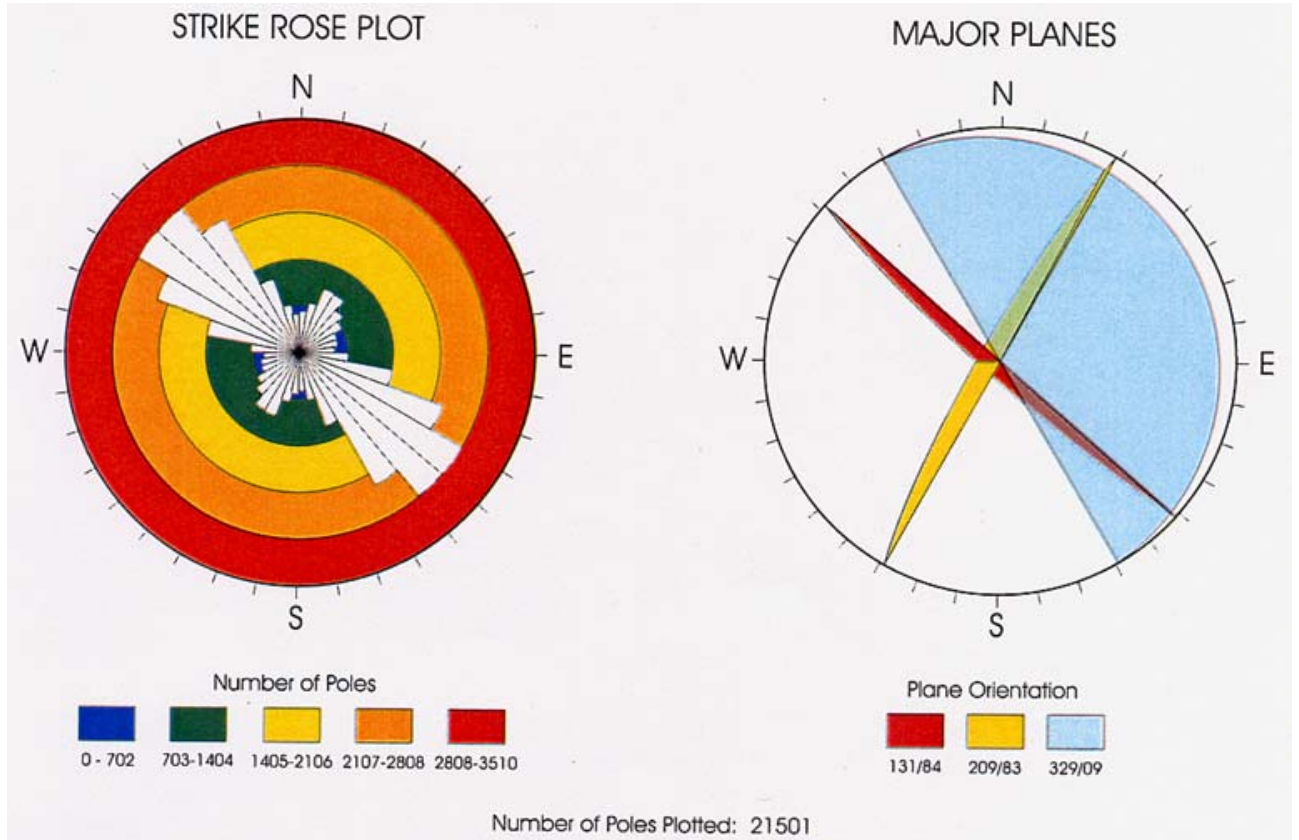

Figure 3b. Graphical illustration of joint rosettes and primary joint sets within units (b) Tptpmn. Developed using stereographic-projection techniques (from NiederWestermann, 2000). 


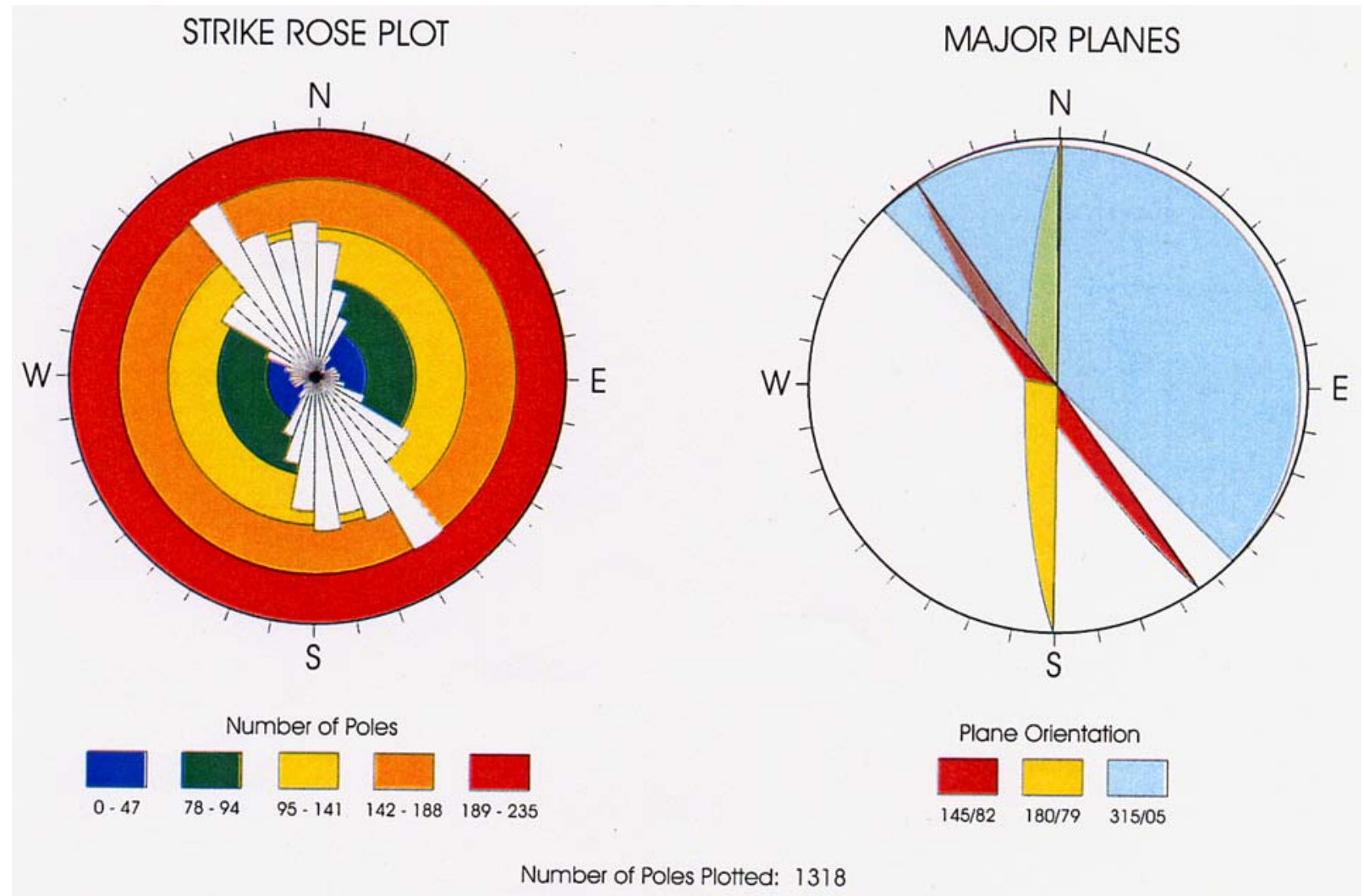

Figure 3c. Graphical illustration of joint rosettes and primary joint sets within units (c) Tptpll. Developed using stereographic-projection techniques (from NiederWestermann, 2000). 


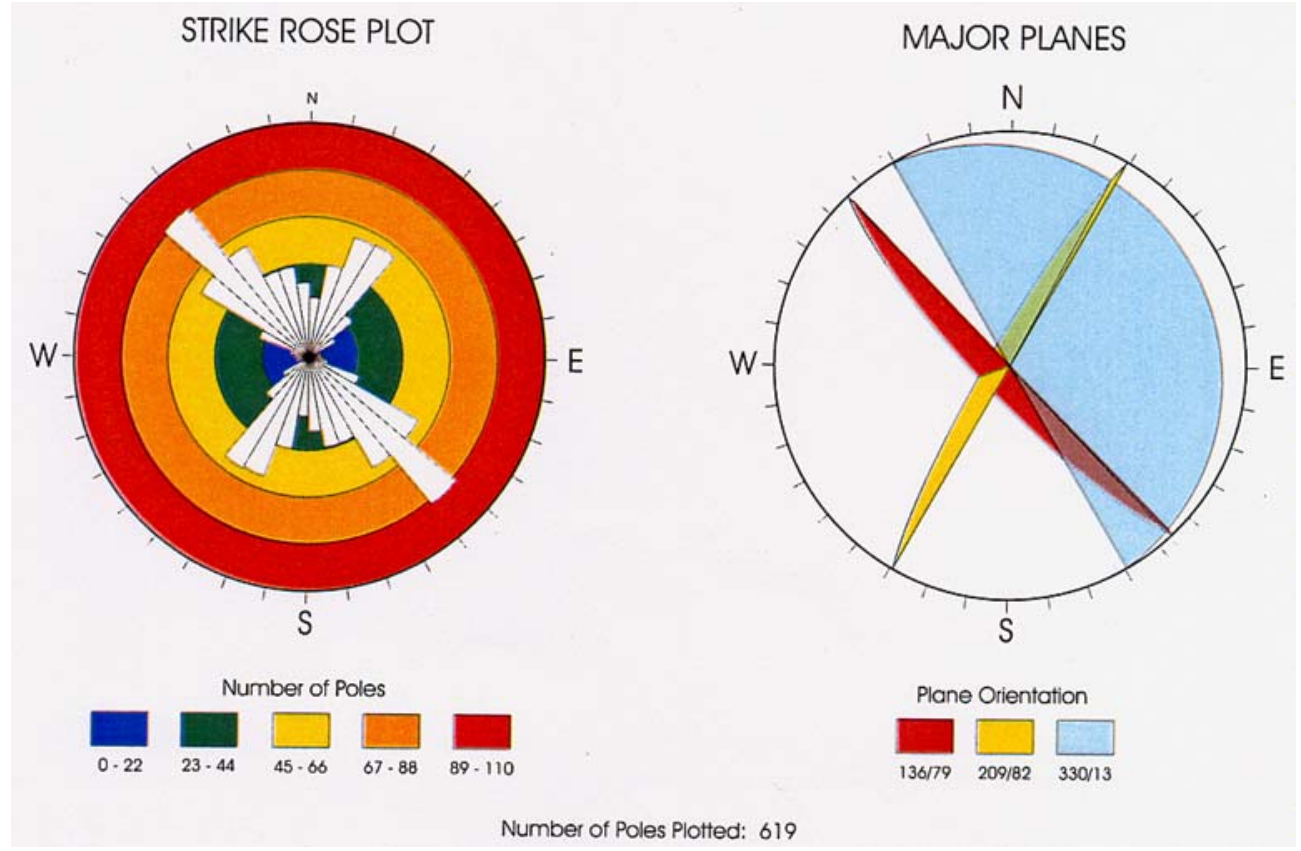

Figure 3d. Graphical illustration of joint rosettes and primary joint sets within units (d) Tptpln. Developed using stereographic-projection techniques (from NiederWestermann, 2000). 


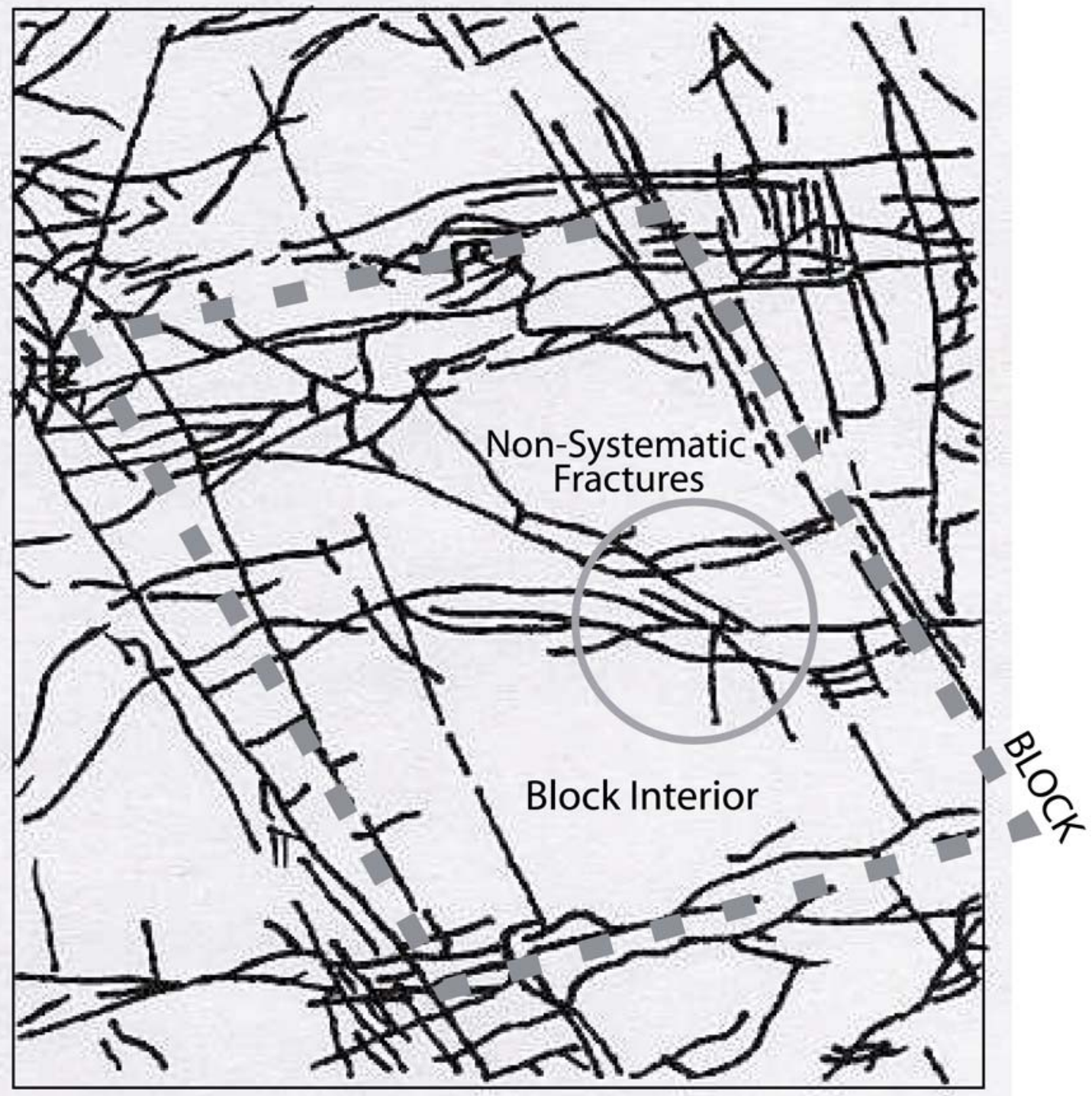

Figure 4. Schematic of a matrix block defined by intersecting systematic joint sets, with the block interior displaying nonsystematic fracturing. 


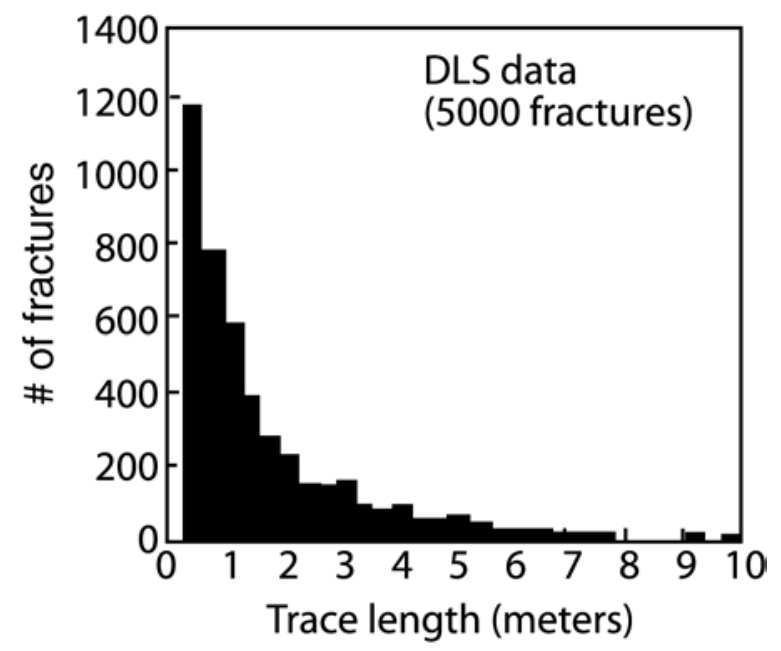

Figure 5. Trace-length distribution of all fractures longer than $0.3 \mathrm{~m}$ measured by the DLS over a $3 \mathrm{~km}$ length in the ESF (from Sweetkind et al., 1997a). 
(a)

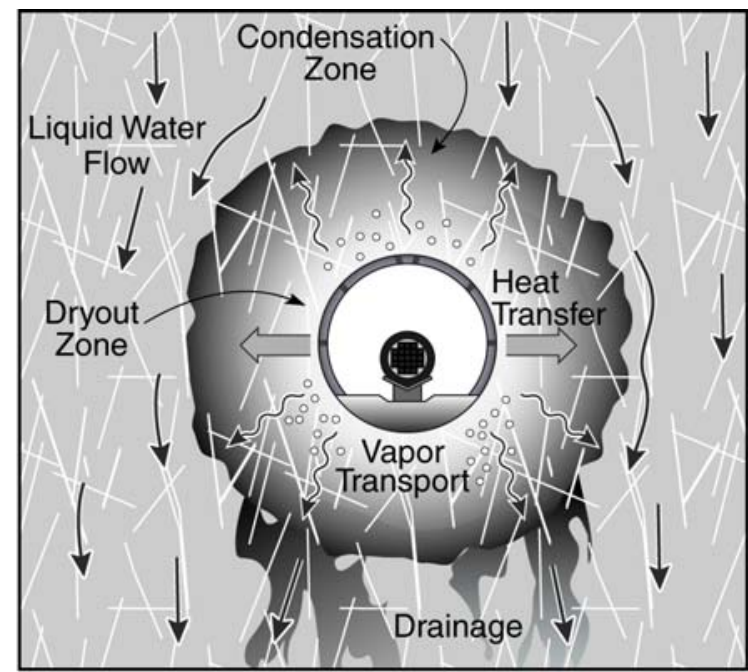

(b)

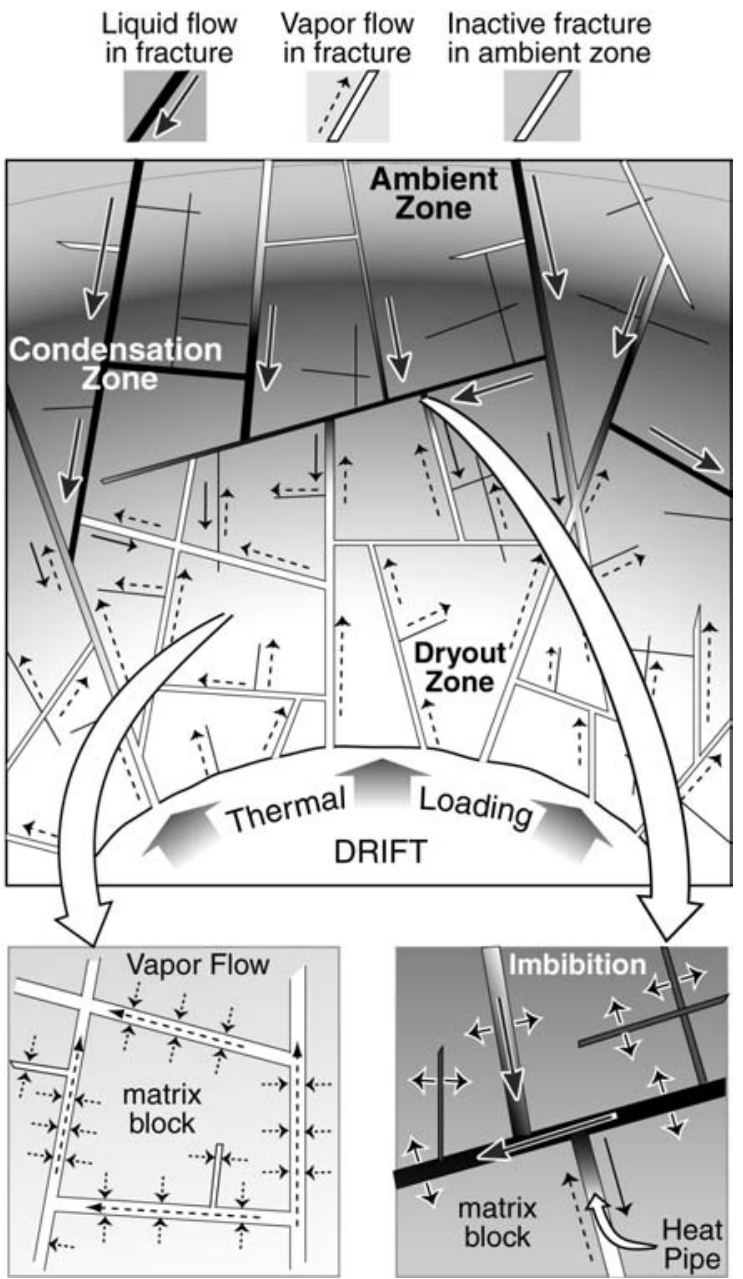

Figure 6. Conceptualization of the hydrological significance of fractures in the near-drift environment during the thermal period: (a) drift-scale overview, (b) detailed water movement above a drift. 
Table 1. Summary of fracture geometric characteristics for RHH units (NiederWestermann, 2000).

\begin{tabular}{|c|c|c|c|c|c|c|}
\hline $\begin{array}{c}\text { Stratigraphic } \\
\text { Unit }\end{array}$ & $\begin{array}{c}\text { Joint Set } \\
\text { Identification } \\
\text { (from FPGMs) }\end{array}$ & $\begin{array}{c}\text { Strike/Dip } \\
\text { (degrees) }\end{array}$ & $\begin{array}{c}\text { Average } \\
\text { Spacing } \\
\text { (meters) }\end{array}$ & $\begin{array}{c}\text { Median } \\
\text { Spacing } \\
\text { (meters) }\end{array}$ & $\begin{array}{c}\text { Average } \\
\text { Trace } \\
\text { Length } \\
\text { (meters) }\end{array}$ & $\begin{array}{c}\text { Median } \\
\text { Trace } \\
\text { Length } \\
\text { (meters) }\end{array}$ \\
\hline \multirow{5}{*}{ Tptpul } & JS-1 & $186 / 82$ & 3.47 & 2.20 & 3.50 & 2.13 \\
\cline { 2 - 7 } & JS-2 & $121 / 83$ & 3.74 & 2.29 & 2.85 & 2.08 \\
\cline { 2 - 7 } & JS-3 & $156 / 81$ & 3.78 & 1.92 & 2.91 & 2.20 \\
\cline { 2 - 7 } & JS-4 & $210 / 82$ & 4.05 & 2.46 & 3.07 & 2.10 \\
\cline { 2 - 7 } & JS-subhorizontal & $310 / 14$ & 3.21 & 1.54 & 5.16 & 4.10 \\
\cline { 2 - 7 } & JS-medium dip & $307 / 47$ & 4.58 & 2.68 & 8.29 & 6.90 \\
\hline \multirow{5}{*}{ Tptpmn } & Unassigned & NA & NA & NA & 3.85 & 2.10 \\
\cline { 2 - 7 } & JS-1 & $131 / 84$ & 0.60 & 0.22 & 2.54 & 2.03 \\
\cline { 2 - 7 } & JS-subhorizontal & $329 / 09$ & 0.56 & 0.29 & 3.23 & 2.06 \\
\cline { 2 - 7 } & Unassigned & NA & NA & NA & 2.54 & 1.90 \\
\hline \multirow{5}{*}{ Tptpll } & JS-1 & $145 / 82$ & 3.47 & 1.57 & 4.56 & 2.11 \\
\cline { 2 - 7 } & JS-2 & $180 / 79$ & 4.05 & 3.18 & 4.02 & 1.70 \\
\cline { 2 - 7 } & JS-subhorizontal & $315 / 05$ & 2.94 & 0.57 & 7.36 & 3.42 \\
\cline { 2 - 7 } & Unassigned & NA & NA & NA & 3.24 & 1.88 \\
\hline \multirow{5}{*}{ Tptpln } & JS-1 & $136 / 79$ & 1.44 & 0.74 & 4.07 & 2.30 \\
\cline { 2 - 7 } & JS-subhorizontal & $330 / 13$ & 2.85 & 1.64 & 1.55 & 1.27 \\
\cline { 2 - 7 } & Unassigned & NA & NA & NA & 4.25 & 1.86 \\
\hline \multirow{5}{*}{} & JS-2 & $209 / 82$ & 2.51 & 1.36 & 4.61 & 1.89 \\
\hline
\end{tabular}

Note: Statistical examination is based on only those fractures with trace lengths greater than or equal to 1 meter. 
Table 2. Average fracture permeability for RHH units based on borehole air-injection tests (from Liu et al., 2000).

\begin{tabular}{|c|c|c|c|c|c|}
\hline \multirow{2}{*}{$\begin{array}{c}\text { Stratigraphic } \\
\text { Unit }\end{array}$} & Basis & $\mathbf{k}_{\mathbf{G}}$ & $\log \left(\mathbf{k}_{\mathbf{G}}\right)$ & $\begin{array}{c}\text { St. Dev. } \\
{\left[\mathbf{l o g}_{\mathbf{(}} \mathbf{)}\right)}\end{array}$ & $\begin{array}{c}\# \text { of } \\
\text { meas. }\end{array}$ \\
\cline { 2 - 6 } Tptr1/Tptpul & $\begin{array}{c}\text { NRG-6, NRG-7a, } \\
\text { SD-12, UZ\#16 }\end{array}$ & $7.7 \mathrm{E}-13$ & -12.112 & 0.612 & 27 \\
\hline Tptpmn & $\begin{array}{c}\text { Alcove 5, NRG-6, } \\
\text { NRG-7a, SD-12, } \\
\text { UZ\#16 }\end{array}$ & $3.4 \mathrm{E}-13$ & -12.474 & 0.546 & 180 \\
\hline Tptpll & NRG-7a, UZ\#16 & $9.0 \mathrm{E}-13$ & -12.044 & 0.544 & 31 \\
\hline Tptpln & SD-12, UZ\#16 & $1.4 \mathrm{E}-12$ & -11.868 & 0.285 & 19 \\
\hline
\end{tabular}

Note: NRG-6, NRG-7a, SD-12, and UZ\#16 are all surface-based vertical boreholes, while Alcove 5 is an access drift located off of the Main Drift of the ESF. 